\title{
买 GENESIS OF THE ISLAMIC STATE AND ITS REFLECTIONS ON THE SECURITY OF WESTERN BALKAN COUNTRIES*
}

\author{
Slobodan Anđelković \\ University UNION - Nikola Tesla, \\ Faculty of International Politics and Security \\ Nebojša Vuković \\ Ministry of defence of the Republic of Serbia, Serbian Armed Forces \\ Željko Lazić \\ Academy for National Security, Belgrade
}

\begin{abstract}
All Western Balkan countries are, more or less, affected by the problem of modern day Islamic extremism and terrorism, which is, directly or indirectly, associated with the activity of the Islamic State in Iraq and Syria. The development of this terrorist organization is characterized by specific social conditions, created after the liquidation of Bin Laden, which practically minimized the role of Al-Qaeda as a global representative of Islamic terrorism. State-forming pretensions of the Islamic state, as a militant organization, indicate political goals, among which the most ambitious of all goals stands out - the creation of a Sunni-Muslim state with a Caliphate as the official form of government. The number of combatants, paramilitary and para-state structures indicate an unparalleled level of sophistication and the highest degree of organization that has ever been seen in a terrorist organization. Repatriated combatants from the Islamic State, who originate from the Western Balkans, represent an undisputable security challenge and a generator of violent extremist views, embodied in the examples of last year's attacks on a police station in Zvornik, and clashes in Kumanovo. The current problem of uncontrolled influx of migrants who arrive from regions which are either under control of the Islamic State, or influenced by it, can reflect significant security consequences on the countries of the European Union, in which these migrants are settling in, but also on the transit countries of the Western Balkans.
\end{abstract}

Key words: Islamic State, extremism, Western Balkans, religion, political extremism, Islam, Islamic fundamentalism, terrorism, terrorist organizations

* Translated by MA Dragan Stanar, Faculty of International Politics and Security, University UNION - Nikola Tesla. 


\section{Introductory remarks}

slamic State (IS), i.e. Islamic State of Iraq and Syria or Islamic State of Iraq and al-

Sham, ${ }^{1}$ (Arabic, ad-Dawlah al-Islāmīyah fīl-'Iraq wa ash-Shām), also known by the acronyms ISIS or ISIL (Islamic State of Iraq and Syria; Islamic State of Iraq and Levant ${ }^{2}$ ), or DAESH ${ }^{3}$ (Arabic, al-Dawlah al-Islamīyah fī al-'Irāq wa-al-Shām), represents an extremely aggressive and well organized extremist militant organization which aims to become a global representative of Islamic terrorism. It is an organization with transparent doctrine, which aspires to create a global Caliphate as an all-Islamic state ruled by Sharia law and original fundamentalist principles, upon which Islam is based. It considers all Shia-Muslims, Jews and Christians as its enemies. Its name represents its goal.

This paper will attempt to explore the rise of IS and its influence on the Western Balkan countries, particularly on establishing the doctrine of religious-political extremism, and thus the creation of new forms of terrorism. Even though this represents an international problem, which was primarily created on the territory of Iraq, Syria, Yemen, Libya and some Northern African countries, tendencies obviously exist for it to spread to other parts of the world. In spite of this fact, this phenomenon has not been properly analyzed in expert and academic community, which is clearly indicated by the fact that large global powers do not have any adequate solution to the problem, neither military nor political. Fundamental social interest is to clarify the conditions in which a new terrorist organization arises, what are its goals, and to what extend does the political extremism it implements inspires the creation of terrorism in any part of the world, and especially the causal geopolitical and security reflections on the Western Balkan region. To deal with this problem means to compare specific historical conditions in certain regions, in which different social and political factors often intertwine. Therefore, establishing precise limits and definitions within ideological foundations of modern Islamic terrorism and political extremism, as its base, is very complex, but still crucially important for the research of topical phenomenon and processes in political science.

In recent years, significant geopolitical escalations took place in the Middle East and Northern Africa, characterized by inter-ethnic and religious armed conflicts, separatist tendencies, as well as hatred and bigotry between different ethnical groups in the Arab world. These events took place under the auspices of the Arab Spring, through the lens of establishing democracy and overthrowing regimes in Libya, Egypt, Tunisia and Syria. Tactics of destabilization conducted by foreign powers, using military, political and economic interventions, are undoubtedly among the conditions which influenced the creation and development of the Islamic State. The increasing Islamic extremism is a direct consequence of these actions, and it contributed to the development of this

\footnotetext{
${ }^{1}$ Sham region, a former Syrian province, included territories of modern day Syria, Lebanon, Jordan, Israel and Palestine.

2 "Levant", in a broader sense, includes the East, i.e. eastern countries, and refers to the Middle-Eastern region which is oriented towards the Mediterranean; territorial determinant similar to the Sham region.

${ }^{3}$ The term DAESH is considered offensive by the members of the Islamic State, and the penalty for using it, in the territory they control, is 70 lashes of the whip. Members of the IS usually refer to their organization as ilDawla, meaning the state. See more at the European Council on Foreign Relations website http://www.ecfr.eu/article/commentary_syrias_uprising_within an_uprising238, accessed on 30/07/2016
} 
terrorist organization, which is in many aspects unparalleled. Its transparent doctrine is embodied in its very name, i.e. the attempt to create a religiously homogenous Sunni state. The territory which the IS considers its Caliphate, allegedly includes almost half of Asia and Africa, as well as a part of Europe (particularly the Iberian and Balkan peninsula). It goes without saying that this example only confirms the rule, that every political extremism represents a negation of a democratic, constitutional state, regardless of how the extremism might manifest itself in practice (through racism, xenophobia, and similar forms, or through the extremes, like in the case of Islamic terrorism).

The influence of IS on the countries of the Western Balkans is realized in various ways. Direct (explicit) manifestation is possible through the actions of armed groups or individuals, like the attacks in towns of Zvornik and Kumanovo, which happened last year. On the other hand, the influence of repatriated jihadists from the IS is significant, and especially their contribution to the radicalization of the environment they live and operate in. Also, indirect influence can be felt through the massive influx of migrants from the areas controlled by the Islamic State, which represents a severe security risk both for the European Union, and all the Western Balkan countries. ${ }^{5}$ There is a concern that, besides France, Belgium and Germany, and Republic of Serbia could also come under fire, primarily due to its heritage of recent conflicts and its geopolitical position, along with Macedonia and Bosnia and Herzegovina.

\section{The Genesis and Development of the Islamic State}

The radical world of Islam, and its current socio-political connotations, which influenced the creation of the Islamic State, represents too complex of a social category, for the West to have a simplified notion of it, as established terrorists and enemies of civilization. It is superficial and naïve to say that IS consists solely of terrorists, and that they will parish once they are military defeated ${ }^{6}$, all the more so because what seem to be joint efforts of leading world powers, are providing no success, for quite some time.

The problem of radical Islamism has deeper roots. It is an undisputable fact that religion is an irreplaceable element of Islamic extremism and terrorism. The majority of terrorist organizations derive their ideology from a radical interpretation of Islam. It is also noticeable that extremism is, in practice, often times equated with terrorism, and terrorism is often times equated with other forms of political violence." "Terrorism... begins with a conspiracy and ends with an overt act," ${ }^{8}$ while extremism lurks behind the scenes, and at the same time has the potential to produce far graver consequences than the terrorist act itself. In accordance with this, it can be concluded that extremism includes all political understandings and behaviors (of individuals, groups, organizations) which drastically

\footnotetext{
${ }^{4}$ DiterNolek, editor, Politikološkiriječnik; (Osijek: Državaipolitika, 2001), pages 310-314.

${ }^{5}$ Having the frequency of the "Balkans route" in mind

${ }^{6}$ Alastair Crook, (presented at the Advanced Course on International Relations - Geopolitics in the Emerging Multipolar Era, Belgrade, Serbia, July $30^{\text {th }}-$ August $6^{\text {th }}, 2015$ )

${ }^{7}$ See more on defining the term terrorism in: Hoffman, B. Inside terrorism,(New York: Columbia University Press, 2006)

${ }^{8}$ Stephen E. Atkins, Encyclopedia of Modern Worldwide Extremist and Extremist Groups, (London: Greenwood, 2004)
} 
deviate from what is acceptable, legal and legitimate in political relations and struggles in a democratic society. ${ }^{9}$ Only in the indirect sense, extremism implies the use of violence, and thus it is concluded that extremism is more of an attitude, than it is an action, and that it appears as a consequence of mutual social prejudice with deep roots ${ }^{10}$.

In the attempt to explain the flagrant development of the Islamic State, the issue of social conditions which led to the creation of this organization inevitably arises. The environment in which the IS was created is complex and characterized by numerous sociopolitical relations and tensions which pervade the entire region, going back almost one hundred years. Countries of the Middle East and Northern Africa were, thanks to their specific mentality and consequences of former colonial government, a breeding ground for the development of Islamic movements. The triumph of Israel in the Arab-Israeli war in 1967. additionally accelerated the process, along with the Western interventions in the Gulf War, and later in Iraq, but also with the rise of Al-Qaeda and promotion of global jihadism. The mentioned effects had, and still have, a powerful influence, predominantly on young people, usually from the middle class and of medium level of education, which became sympathizers and members of political-extremist and terrorist groups. ${ }^{11}$ Islamic State offers the Muslims the utopia of global Caliphate, thereto achieving significant military results in the region of Iraq and Syria. IS created a Sunni "state" which is larger than Great Britain, and in a territory in which the Sunni were "oppressed" by the Shia majority, even by the Kurds.

Critical events in the Middle East and Northern Africa began with the wave of the socalled Arab Spring, which started with the revolution in Tunisia, in 2011, and was then carried over to Egypt, Libya and Syria, where it gained a special dimension, and, according to many, got out of control. Namely, the civil war, which has been raging in Syria for two years now, along with the conflicts in the surroundings, is characterized by complex religious and political relations. President Bashar al-Assad, who belongs to the Alawite branch of Islam, is at the head of the Syrian Arab Republic, a country where the Sunni majority makes about $75 \%$ of population, and do not even consider Alawites as Muslims. Besides being a religious group, Alawites are also an ethnical group, similar to Jews and other groups in the Middle East, which were, to some extent, created by religion, which then gave them a crucial determinant of their national identity. Surely the hostility between two denominations of Islam, Shias and Sunnis, is not visible exclusively in Syria. The majority of population in Iraq are Shias, even though Saddam Hussein, a Sunni, ruled Iraq for decades. An armed conflict of limited intensity is active in Yemen, which is also governed by a Sunni ruler (president Abd Rabbuh Mansur Hadi), who rules ${ }^{12}$ an equally numerous Shia population. ${ }^{13}$

\footnotetext{
${ }^{9}$ See more on the notion of extremism in: Marija R. Đorić, "Teorijsko određenje ekstremizma“, Kultura polisa, IX, 17, 2012, pages 45-62.

${ }^{10}$ Islamic Extremism: Common concern for Muslim and western public", 17 Nation Pew Global Attitudes Survey, The Pew Global Attitudes Project, 2005.

${ }^{11}$ Randy Borum, Psychology of Terrorism, (Tampa: University of South Florida), accessed on 01/10/2015

${ }^{12}$ It is highly questionable whether Hadi is ruling Yemen or not, considering that the rebel groups, mostly consisting of Shia Muslims, took the capital Sana'a in February of this year. Hadi enjoys the support of the majority of the Gulf and Middle-Eastern Sunni countries, primarily in the political, but also in the military segment.

${ }^{13}$ See more on political and religious situation in the Middle East in: Lee, R. and Shitrit, B.L,Religion, Society, and Politics in the Middle East, chapter 5, CQ Pres, 2013,available at: http://www.cqpress.com/docs/college/Lust_Middle\%20East\%2013e.pdf, accessed on 08/10/2015
} 
Islamic State, as we know it today, was formed by the merger of Islamic State in Iraq, led by al-Baghdadi and al-Qaeda in Iraq ${ }^{14}$, with initial support of individuals from the alNusra Front and other Islamic groups. The key factor is that the entre process took place in the moment when Bin-Laden was executed, and Al-Qaeda, as the umbrella organization for virtually all Islamic terrorist groups, almost completely disappeared from the scene. It can be said that IS is somewhat of an offspring of Al-Qaeda, ${ }^{15}$ i.e. an organization from which it separated in time (or transformed into its modern form), since IS considers that it surpassed Al-Qaeda, and that it has higher goals. ${ }^{16}$ Besides the mentioned, the Arab Spring, and especially the war in Syria, are of pivotal importance for the amazing growth of IS. In a very complex political-security situation, Western powers, pursuing their own geopolitical interests (primarily in the attempt to limit the influence of Russia, China and Iran in the region), supported the rebels who rose against Assad's regime. In such conditions, the spillover of the mentioned support inevitably occurred, from the so-called "Free Syrian Army" and other militant groups, which were acceptable allies, to Islamic groups, following the principle "the enemy of my enemy is my friend." The exact number of personnel that IS has is still unknown; their strength is evaluated at around 50.000 fighters or more, of which approximately 20.000 from abroad ${ }^{17}$.

The organization sees itself as a seed from which a transnational Islamic state will sprout, on the territory of Iraq and Syria, as a separate geographical entity. It has combat formations which resemble a conventional army, which inflicts grave losses, both to Syrian and to Iraqi army. It also enjoys a significant support from the common people, who are attracted to the aspiration to transform the radical Sunni movement into a regional state. IS prints money, trades oil, even makes informal international agreements (like the one with Turkey, regarding fighting against the Kurds in exchange for weapons transfer), and to top it all, it controls a large territory. Considering that the Western model of democracy proved to be inapplicable in the Islam mentality, and after military interventions and aspirations for immoderate draining of natural resources, from the standpoint of Islam traditionalists the IS represents a starting point for the fight against globalization, led by the United States. On the other hand, radical Islam implemented by the Islamic State, in the Middle East and Northern Africa, is achieving goals which are identical to the goals of globalization - it is destroying great cultural worlds (unfortunately, in a military sense of the word) and aims to master political and economic space.

Islamic State is also a byproduct of anti-Shia and anti-Iranian fundamentalist struggle, financially aided by Saudi Arabia. Through the geopolitical prism, fundamental interest of Saudi Arabia is not to allow the creation of the so-called "Shia transversal" which would connect Iran and Lebanon (populated by Shia Muslims). On the other side, geoeconomic motives of Iran are obvious - establishing a massive unified market. Creating

\footnotetext{
${ }^{14}$ Also known as the Al-Qaeda of the Arabian peninsula

15 ISIL differs from Al-Qaeda in numerous things; while Al-Qaeda used one country and its logistics (Afghanistan), ISIL strives to create a state of its own. Unlike Al-Qaeda, al-Baghdadi conquers and keeps territories, ruthlessly dealing with his enemies. It is more sophisticated than Al-Qaeda, it is a dream come true for the extremists, a dream of "genuine Muslim state" and as such, attracts a large number of supporters

${ }^{16}$ Dragan Simeunović, "Islamska država”, Geopolitika, 2015 (May $12^{\text {th }}$ ), page 10.

${ }^{17}$ See more on number of foreign fighters in Syria and Iraq: Foreign Fighters, An Updated Assessment of the Flow of Foreign Fighters into Syria and Iraq, The Soufan Group, December 2015
} 
an onshore connection of territories situated between the Indian Ocean (Persian Gulf) and the Mediterranean, avoiding the Gulf of Aden and the Suez Canal, is highlighted as its geostrategic interest.

\section{Reflections of the Islamic State Activity on the Western Balkan countries}

Every terrorism is, in fact, realized extremism. Extremism is generated in different regions, and especially in communities which were governed by undemocratic regimes for an extended period of time, that is to say, where processes like political integration and society modernization remain unfinished. Psychological propensity for extremism in our region was noted by the classic of our etno-psyhology, Vladimir Dvorniković, stating that: "a Yugoslavian man, in accordance with his intellectual dispositions - is a political extremist." This goes to favor the claim that the history of our region was partially conditioned by its geographical position, as well as the psychological foundation of the Balkan peninsula's population.

Current political and security situation in the Balkans has reached its most difficult point since the end of the wars that happened in the '90s. Today, the region is economically, politically and security-wise partially integrated in the European Union architecture, and accordingly in European security structures, but we witness that this concept faces great challenges today. ${ }^{19}$ What today concerns Europe and the Balkans the most, security-wise, is the development of the Islamic State on a large part of the territory of Iraq and Syria, as well as other African and Middle-Eastern countries. Finally, the humanitarian crisis, which is caused by an unstoppable wave of refugees from that region, has an expressed economic and security connotation. All these factors make the security situation in the Western Balkan region extremely complex and uncertain. Recent messages of representatives of the Islamic State, directed at the Balkan countries (in the form of a musical vide ${ }^{20}$ ), in which the jihadists announce their arrival, conquering of this region and establishing a Caliphate, shook the region to the core, a region which faces an increasing level of similar threats coming from radical Islamists.

The occurrence of jihadism in our region in the 1990s can be interpreted, from a political standpoint, as the emergence of extreme Muslim right wing. The consequences of these occurrences are reflected in the fact that 10 Wahhabi enclaves are established in Bosnia and Herzegovina, populated by 3.000 Wahhabis, predominantly financially supported by various "humanitarian organizations" from Saudi Arabia". In these environments, the Koran and Sharia (which are considered God's law) become two basic

\footnotetext{
${ }^{18}$ Vladimir Dvorniković, Karakterologija Jugoslovena, (Belgrade: Prosveta, 1990)

${ }^{19}$ Security concept of the European Union is primarily based on economy and politics, and then characterized by the fact that most EU members are also NATO members

${ }^{20}$ Video message broadcasted on 10/07/2015, on the internet website http://puthilafeta1.blogspot.rs/

${ }^{21}$ Violent Extremism in the Western Balkans, 31st RSSEE SG WORKSHOP - Belgrade, Serbia 27 - 29 September 2015, available at http://www.bundesheer.at/pdf_pool/publikationen/pfpc_31st_rssee_policy.pdf, accessed on 12/08/2016
} 
sources according to which all legal norms are determined and other types of behavior and lifestyle of individuals and social communities are regulated. ${ }^{22}$ The influence of Muslim priests in those environments, but also in other parts of Europe, is primarily based on resisting assimilation and inclusion in broader social flows, which necessarily creates, in time, a division between "us" and "them". Regarding that the Turkish government has sent 970 clerics - most of whom do not speak German - to lead 900 mosques in Germany that are controlled by a branch of the Turkish Government's Directorate for Religious Affairs. ${ }^{23,}{ }^{24}$ Therefore a conclusion arises, that radicalized communities in Western Balkans, even beyond the Balkans, act as nursery gardens for extremists, of which some individuals are later recruited to perform terrorist acts.

The occurrence of movements which are increasingly spreading their influence in the Western Balkan region, like Wahhabism and Takfiri movement, each inspired by its leader (Al-Wahhab, Shukri Mustafa), still act within the framework of jihadism, as a type of a base for militant Islamic extremists. Jihadism is an ideological option of Islamic fundamentalism, which aspires to realize its religious and political goals using jihad - understood as a "holy war" and directed mostly against USA, Israel, Christians and other infidels, if they are perceived as adequate enemies at a moment. ${ }^{25}$ Negating the right of territory, government or even the right to live, to others represents an exclusive and extremist standpoint, much like Nazism. Only difference being, that in this case, a "higher race" nation was substituted by a nation comprising of "orthodox" Muslims. This exclusivity is a characteristic of Islamic Nazism, expressed in a religious-political form. ${ }^{26}$ As this case is all about glorification of Muslim nation (where religious determinant represents the foundation of national identity) and Muslim state - jihadism represents both fascism and Nazism. ${ }^{27}$ We can come to a conclusion that the relationship between Nazism, clerical fascism and Islamic terrorism does not lie in favoring religions, but rather in the use of fanaticism in religious behavior.

Security risk brought by the repatriated combatants of the IS, consists of their capability to perform complex attacks, as they are integrated in the environment, know the language and have a better network, enabling them to plan and execute terrorist acts unnoticed. This represents an obvious advantage over an infiltrated group of foreign citizens, who are to some extent monitored by the security services. According to the data gathered by the Kosovar Center for Security Studies, 232 people from Kosovo and Metohija are involved in the conflicts in Iraq and Syria, at this moment (data from January 2015) ${ }^{28}$. The same source

\footnotetext{
${ }^{22}$ Violeta R. Talović, “Islam kao izvor političke ideologije u Čečeniji”, Kultura polisa, 2013, 21, pages 23-46.

${ }^{23}$ Getestone Institute, International Policy Council, available at https://www.gatestoneinstitute.org/7931/germany-islam-law, accessed on 10/08/2016.

${ }^{24}$ Even though Turkey is, unlike Saudi Arabia, considered a secular state, its political aspirations indicate that it, using religion, is trying to control a vast Turkish population in Germany

${ }^{25}$ See more on the notion of jihad in: Miroljub Jevtić, Džihad, (Belgrade: Nova knjiga, 1989)

${ }^{26}$ Jihadism is a type of fascism, because it is based on xenophobia, hatred to all non-Islamic and non-Islamic related things, with highlighted anti-Judaism. Tendency to determine entire nations as permanent enemies, due to their religious or ethnical diversity, is a universal mean of extreme nationalism and clericalism, and in this sense, Islamic terrorism is based on various nationalisms, like Arab, Bosnian etc.

${ }^{27}$ Nebojša Vuković and Z. Milosavljević, "Politicki oblici ekstremizma", Vojno delo, 2015, 4

28 "Report inquiring into the causes and consequences of Kosovo citizens' involvement as foreign fighters in Syria and Iraq", Kosovar Center for Security Studies, April 2015.
} 
claims that Kosovo tops the list of percentage of combatants involved in the conflicts in the Middle East, in relation to the population, followed by Bosnia and Herzegovina, with Albania coming in fourth. ${ }^{29}$ According to the results of the research conducted by The International Centre for the Study of Radicalisation and Political Violence in London, there are about 11.000 foreign fighters in IS formations, mostly from France, Germany and Great Britain ${ }^{30}$ (when we consider European countries). The presence of foreign terrorist fighters (FTFs) additionally raises the intensity and duration of the conflict, affecting the security situation in their countries of origin, transit and final destination, as well as in the surrounding countries. The United Nations Security Council Counter-Terrorism Committee estimates that about 25.000 people, from about 100 different countries, spent time in conflict zones in Iraq and Syria, ${ }^{31}$ which suggests potential religious-political indoctrination of a large number of people.

Potential attacks would definitely destabilize the situation in Western Balkan countries, which are currently at different levels of integration in the Euro-Atlantic security structures. It seems obvious that recent war events and unsolved political circumstances in Serbia, along with the registered presence of Islamic extremists in some regions of Serbia, Bosnia and Herzegovina and Autonomous Province of Kosovo and Metohija, can act as a motive for destabilization of the country. The recently broadcasted video message represents an attempt of the IS to expand, and somewhat promote, its operation to the territory of Serbia, which was labeled as the main target in numerous jihadi messages, Bosnia and Herzegovina, Montenegro and Macedonia. However, the IS does not possess the operational-financial capacities to initiate large-scale operations in this region. ${ }^{32}$ Also, potential terrorist targets in the Western Balkan region are not as striking, media-wise, as those in Western Europe. Objectively, ISIS can expand in the region where it was created, meaning the areas of weak and war shook countries like Iraq and Syria, as well as the region of Northern Africa. ${ }^{33}$ Islamic State, as well as other terrorist organizations, is not to be underestimated, because even though it cannot establish a global Caliphate, isolated terrorist attacks have been proven to be easily achievable. Recent terrorist attacks in Paris, Brussels, Nice and Munich serve as a reminder of this fact.

The return of the IS combatants in the environments they originated from only promotes the radicalization of the entire region. It is a viable claim that the Western Balkan region is, we can now even say traditionally, a stronghold of extreme Islamists. Regarding this claim, it is important to emphasize that violent extremist movements in the Western Balkans are not a creation of the new age, that is to say that certain segments of society have already been indoctrinated with Islamic extremism, particularly during the wars in the 1990s. Radical Islamists-Salafists are ingrained among Muslims in the

\footnotetext{
${ }^{29}$ Ibid.

${ }^{30}$ ICSR, Department of War Studies, King's College London , http://icsr.info/projects/western-foreign-fighterssyria/, accessed on 08/01/2016.

${ }^{31}$ http://www.un.org/en/sc/ctc/docs/2015/0721Special\%20Meeting\%20Madrid\%20\%20General\%20background\%20Note.pdf, accessed on 08/01/2016

${ }^{32}$ It should also be kept in mind that the IS considers the Iberian Peninsula as a part of the Caliphate

${ }^{33}$ The spreading of the Islamic State on the region of Turkey is also practically impossible, because Turkey is an important strategical partner of the US, and it aspires to become a member of the EU
} 
Balkans, who are predominantly followers of the Hanafi school of Islam. Unsolved national quarrels, religious fundamentalism, which is increasingly present in Bosnia and Herzegovina and the Autonomous Province of Kosovo and Metohija, along with the fact that a significant Albanian population is present in the south of Serbia, ex members of the so-called KLA and LAPMB with territorial aspirations in that region of Serbia, all affect this complex situation. Also, the presence of Wahhabis in Raška region and constant political tension carried out by some Muslim religious leaders, indicate potential hotspots suitable for actions of combatants who return from the Middle East, having their extremist views and combat experience in mind. This is especially the case in Bosnia and Herzegovina and Kosovo, where some foreign participants of former conflicts in this region settled. Large number of mujahidin, who represent the legacy of former conflicts and who were completely protected and hidden after the war, are present in these territories.

Armed conflicts in Syria, Iraq, Afghanistan, Jordan, Libya and other countries in the Middle East and Northern Africa, resulted in a massive migration of the population, directed towards the countries of the European Union, particularly Germany and Scandinavian countries. Migrant crisis further emphasized deep roots of ethnicity of European national states. The fact that fences are being built between states members of the EU, that inter-state public transport lines are being terminated, and that the Schengen Agreement is being contested and even, to some extent, suspended, supports the claim. Having in mind the number of refugees and inability to efficiently register them and perform security checks, migrant crises gained a pronounced security character, in addition to the humanitarian. Refugee wave which flooded Serbia, enabled a severe number of potential terrorists to infiltrate the countries of the $E U$, but also the Western Balkan region, which serves as a transit region for this process. Besides the direct security challenges, a conclusion indirectly arises, that too large of a population migration (of Muslim religion, mostly male) can cause a shift in the ethnical map of certain regions of the European Union, which can have future implications on security.

Reactions of some Western Balkan countries clearly indicate that the influence of the IS on this region has been recognized as an undoubtable security challenge. The mentioned information regarding the number of combatants who originate from this region, and who are in the IS formations at this moment, support the claim that all local secular regimes are equally affected by the same problem. The success of national counter-terrorist systems significantly depends on the state of terrorism and the level of terrorist threats to the region, especially in neighboring countries. A potential way for the Western Balkan countries to successfully face terrorism is to create some type of a joint operational-coordination headquarters, which would also include the international forces present in the region, to track the individuals who represent a terrorist-rebellious threat. This would make the spillover of terrorism from one country to another much harder, and give counter-terrorism operations a regional character. As a measure of protection against domestic extremist who are fighting in foreign conflicts, (mostly in Syria, Iraq, but also in Ukraine), in large numbers, Republic of Serbia adopted an amendment of the criminal code, which stipulates prison sentences, from 6 months to 10 years, for those individuals who take part in armed conflicts in other countries. In that sense, other regional countries also attempted to find a solution to this problem. 


\section{Conclusion}

It is clear that not a single period in modern history was spared from wars and various conflicts, regardless of the consequences and hindsight conclusions. Geopolitical postulations of conflicts, which can be regarded as the causes of many conflicts, are realized through the aspirations for territorial, political and economic expansion of influence.

Religious fundamentalism is present in all religions, to a greater or lesser extent. However, it is absolutely unacceptable for every religious fundamentalism to be an ideology at the same time; in order to define it in such a way, it has to meet certain conditions: it has to have political goals, it has to possess the appropriate ideological potential for mobilization, and it has to have an offensive character. Islamic fundamentalism has proved itself to be a functional foundation for the generation of Islamic terrorism and other forms of politically motivated violence. These are the very foundations on which Al-Qaeda was formed, followed by Al-Qaeda in Iraq, and finally, the Islamic State, which regenerates and transforms into more advanced forms, like the Hydra (mythological monster). IS achieves its full affirmation riding the wave of the Arab Spring, where United States (and a number of Western countries) play an active role in the proceedings, directly aiding the opponents of Assad's regime, which acted as a catalyst for the development of the organization. Today, IS represents a respectable military-political organization, which conducts large-scale combat operations with quite megalomaniacal political goals.

As political extremism (as a form of political action) is invariably a political, and only then a security, social and anthropological phenomenon, the influence it has on political relations is significant. Political extremism, in any form, is a distinctly negative phenomenon, which almost always generates immeasurable consequences (it starts with the persecution of opponents and dissidents, and end with atrocious crimes). Political extremism is also most often the base for the creation of new types of terrorism, and other forms of political violence, like riots, unrests, political homicides, even rebellions of broader proportions, like insurrections etc. ${ }^{34}$ If the extremists do not have a political goal, we cannot speak of political extremism, and the political goal of the IS is embodied in its name. The occurrence of some new types of Islamic extremism, like Wahhabism and the Takfiri movement, convinces us of its great potential, as well as the tendency to manifest itself across the world (as jihadism). The power of such trends in immense, especially when we have the creation of the Islamic State in mind, which has outgrown even AlQaeda, particularly in massiveness, organization and, the most obvious - brutality.

Direct effect of the IS on the Western Balkan countries is possible by the means of terrorist or other violent acts. Recent attacks on the police station in Zvornik, and fighting in Kumanovo, indicate that the political-security situation in the region is a fertile ground for manifestation of political violence acts. Indirectly, the radicalization of the entire region is obvious, as the consequence of the actions of repatriated combatants from the IS. Countries of the Western Balkans are at the head of the list of the number of volunteers in the Syrian warfare theater, which carries an obvious security risk, along with the

\footnotetext{
${ }^{34}$ See more on forms of political violence in: Dragan Simeunovic, Politicko nasilje, (Beograd: Radnicka stampa, 1989)
} 
mentioned problem, due to the fact that these are men with substantial combat experience. There is no doubt that a large number of IS combatants from the region (Raška region, Kosovo and Metohija, FYR of Macedonia, Bosnia and Herzegovina, Albania) could corresponds with a large number of ISIS fighters from EU and terrorist attacks in Paris, Brussels, Nice and Munich.

After all, previously mentioned attacks on the police station in Zvornik and the attack in Kumanovo, confirm that global jihadism effects the radicalization of the Western Balkans, creating an atmosphere in which political violence is acceptable. Radicalization of the environment, which the repatriated combatants generate, is an already known phenomenon. It encompasses a security connotation conditioned by a large number of people who spent time in Afghanistan during the 1980s, but also those who stayed in Algeria, Somalia, Tajikistan and former Yugoslavia in the 90s, Iraq, Pakistan and Yemen in the 2000s. ${ }^{35}$ Relevant indicators imply that mobilization power of jihadism (in this case IS) is sizable, and that it can inspire individuals to perform terrorist attacks. These potential attacks in some regions of Serbia can even transform into an armed rebellion, especially in parts of the Raška region, where a significant number of Wahhabis is already present, as well as in the south of Serbia, where a large number of extremists is present, among the Albanian population.

Exodus of Middle Eastern nations especially affects Europe, as well as the Western Balkan countries, which face a tremendous economic, humanitarian and security challenge. Sudden influx of migrants, who enter Serbia, additionally complicates security circumstances, and although a huge majority of migrants is fleeing from war conflicts, we must not lose sight of the fact that they will represent the target group for the activity of Islamists. Considering that no country in the Balkans can successfully fight against terrorism and the spillover of terrorism on its own, a necessity for joint execution of this security task, in cooperation with international community forces in the region, imposes it self upon the Balkan countries.

\section{Literature}

[1] Alastair Crook, (presented at the Advanced Course on International Relations - Geopolitics in the Emerging Multipolar Era, Belgrade, Serbia, July 30th-August 6th, 2015).

[2] Diter Nolek, editor, Politikološki riječnik; (Osijek:Država i politika, 2001).

[3] Dragan Simeunović, "Islamska država", Geopolitika, 2015 (May 12th).

[4] Dragan Simeunovic, Politicko nasilje, (Beograd: Radnicka stampa, 1989).

[5] Foreign Fighters, An Updated Assessment of the Flow of Foreign Fighters into Syria and Iraq, The Soufan Group, December 2015.

[6] Hoffman, Bruce. Inside terrorism,(New York: Columbia University Press, 2006).

[7] Islamic Extremism: Common concern for Muslim and western public", 17 Nation Pew Global Attitudes Survey, The Pew Global Attitudes Project, 2005.

[8] Marija R. Đorić, "Teorijsko određenje ekstremizma", Kultura polisa, IX, 17, 2012.

[9] Miroljub Jevtić, Džihad, (Belgrade: Nova knjiga, 1989).

\footnotetext{
${ }^{35}$ http://www.un.org/en/sc/ctc/docs/2015/0721Special\%20Meeting\%20Madrid\%20$\% 20$ General\%20background\%20Note.pdf, accessed on 08/01/2016
} 
Genesis of the Islamic State and its Reflections on the Security of Western Balkan Countries

[10] Nebojša Vuković and Zoran Milosavljević, "Politicki oblici ekstremizma", Vojno delo, 2015, 4.

[11] Randy Borum, Psychology of Terrorism, (Tampa: University of South Florida), accessed on $01 / 10 / 2015$.

[12] "Report inquiring into the causes and consequences of Kosovo citizens' involvement as foreign fighters in Syria and Iraq", Kosovar Center for Security Studies, April 2015.

[13] Stephen E. Atkins, Encyclopedia of Modern Worldwide Extremist and Extremist Groups, (London: Greenwood, 2004).

[14] Violeta R. Talović, "Islam kao izvor političke ideologije u Čečeniji”, Kultura polisa, 2013, 21.

[15] Vladimir Dvorniković, Karakterologija Jugoslovena, (Belgrade: Prosveta, 1990).

\section{Internet sources}

https://www.ncjrs.gov/pdffiles1/nij/grants/208551.pdf

http://www.cqpress.com/docs/college/Lust_Middle\%20East\%2013e.pdf

http://www.aljazeera.com/news/middleeast/2014/08/islamic-state-50000-fighters-syria-

2014819184258421392.html

http://puthilafeta1.blogspot.rs

http://icsr.info/projects/western-foreign-fighters-syria

http://www.un.org/en/sc/ctc/docs/2015/0721Special\%20Meeting\%20Madrid\%20$\% 20$ General\%20background\%20Note.pdf

http://www.un.org/en/sc/ctc/docs/2015/0721Special\%20Meeting\%20Madrid\%20$\% 20$ General\%20background\%20Note.pdf 